\title{
Preemption of Local Laws by the Hazardous Materials Transportation Act
}

While the process of selecting new sites for disposal of hazardous (and particularly nuclear) wastes has attracted great media attention, the problems of transporting hazardous materials have not been as visible, although the dangers may be as great ${ }^{1}$ and the divergence of local and national interests as severe. Nearly all levels of government attempt to control the activity, creating a complex web of regulation ranging from local ordinances simply banning nuclear waste shipments within towns to complex state specifications concerning equipment, routing, and reporting procedures. ${ }^{2}$ Although many of the regulations are intended to promote local safety, they often achieve their purpose by diverting hazardous

1 A 1983 study completed for EPA found that approximately $90 \%$ of offsite transportation of hazardous waste is by truck, and that on average one drum is lost for every three truckloads of hazardous waste. Truck Transport of Wastes as Risky as Treatment, Disposal, Consultant Says, Env'T REP. (BNA) 733 (Sept. 2, 1983). In 1982, shippers reported 6,540 "incidents" and 12 fatalities during the transportation of hazardous materials. HrGHway Safety Act of 1983: Transportation of Hazardous Materials: Hearings on S. 1108 Berore the Senate Comm. on Commerce, Science and Transportation, 98th Cong., 1st Sess. 205 (1983) (opening remarks of Senator Danforth) [hereinafter cited as 1983 HearINGs]. For example, in an average week New Hampshire alone suffers three to five hazardous waste spills during transportation. See New Hampshire Motor Transp. Ass'n v. Flynn, 751 F.2d 43, 47 (1st Cir. 1984).

${ }^{2}$ As of 1981, at least 55 localities and states had attempted to regulate the transportation of hazardous or nuclear materials. See Marten, Regulation of the Transportation of Hazardous Materials: A Critique and a Proposal, 5 HARv. EnvTL. L. REv. 345, 354-56 (1981). The cities of Boston, Dallas, Philadelphia, and New York have comprehensive routing regulations for hazardous-materials transports, and Los Angeles, Lexington, and Gainesville, Florida have seriously considered them. 1983 Hearings, supra note 1, at 298 . For examples of local regulations currently in force but under attack as preempted by federal law, see Illinois Nuclear Safety Preparedness Act, § 4(7), P.A. 83-1342, § 1, ILL. REv. STAT. ch. 1111/2, $\S 4304(7)$ (1985) ( $\$ 1000$ per cask user fee); OHo Rev. Code ANN. $\$ 4163.07$ (Page 1980) (prenotification requirement); OR. REv. STat. § 480.120(1)(a) (1985) (fireworks laws); Prince GEoRge's CounTY, MD. CoDE $\$ 18-187$ (Aug. 10, 1982) (county ordinance), reprinted in Application for Inconsistency Ruling, Docket No. IRA-26, 49 Fed. Reg. 39,260 (1984); Town of Framingham, Mass. By-law (Jan. 27, 1982) (town meeting resolution), reprinted in Application for Non-Preemption Determination, Docket No. IRA-31, 49 Fed. Reg. 3166 (1984).

Vermont town meetings have passed several ordinances simply banning all transportation of hazardous materials within city limits. See Note, The Need for Exacting Legislation Regulating the Shipment of Radioactive Wastes in Vermont, 8 VT. L. REv. 407, 414-15 (1983). For examples of state specifications, see infra notes $48,69-73$ and accompanying text. 
materials from one jurisdiction into another, which may decrease net safety and arbitrarily redirect traffic away from optimal routes.

In 1974, Congress enacted the Hazardous Materials Transportation Act to consolidate federal authority over this subject area. ${ }^{3}$ The HMTA vests the federal Department of Transportation with principal responsibility over the Act's unification scheme, ${ }^{4}$ pursuant to which DOT has issued copious regulations. ${ }^{8}$ But the addition of a new regulatory layer, far from ending the confusion, has merely intensified it. In large part, the HMTA's failure can be traced to uncertainty over the critical question of when federal regulations preempt those of states and localities. On this issue DOT and the courts have adopted widely divergent approaches.

This comment reviews the interaction between the HMTA and local laws and proposes steps that the courts, DOT, and Congress should take to clarify the roles of national and local authorities. Part I examines the statutory framework for deciding preemption under the HMTA and summarizes the approaches that DOT and various courts take to preemption. This part also criticizes current approaches and points out the uncertainties that result from current procedures. Part II suggests a more satisfying analytical framework for considering HMTA preemption issues and proposes ways in which Congress might clarify the scope of DOT and local authority.

s Act of January 3, 1975, Pub. L. No. 93-633, title I, 88 Stat. 2156 (codified at 49 U.S.C. $\S \S 1801-1812(1982))$.

' S. REP. No. 1192, 93d Cong., 2d Sess. 1 (1974). Several other federal agencies also claim to have responsibilities in this area. For example, after passage of the HMTA, the Resource Conservation and Recovery Act of 1976, 42 U.S.C. $\$ \$ 6901-6987$ (1982 \& 1985 Supp.), explicitly granted the Environmental Protection Agency authority over transporters of hazardous waste to guard against environmental harms. In addition, the Nuclear Regulatory Commission, Interstate Commerce Commission, OSHA, and the Coast Guard may all have some continuing authority over various aspects of the field. See Memorandum of Understanding, 44 Fed. Reg. 38,690 (1979) (NRC and DOT agreement); Akron, C. \& Y. R.R. v. ICC, 611 F.2d 1162, 1169 (6th Cir. 1979) (discussing ICC's continuing role); Frye, Recent Developments in the Transportation of Hazardous Materials, 10 Transp. L.J. 97 (1979) (discussing OSHA's role). For an outsider's view of the complex regulatory structure facing a shipper of hazardous waste and a comparison to the Canadian system, see Vomberg, Regulating the Transportation of Dangerous Goods, 21 ALBERTA L. REv. 488, 506-07 (1983); see also Hillier, Transportation of Dangerous Substances, 31 U. NEw Brunswick L.J. 135, 15960 (1982).

s See 49 C.F.R. $\$ \S 171-179$ (1984). An official of the port of Seattle described these federal regulations, which total well over a thousand pages, as "fine print an inch and a half thick, requiring a Ph.D. chemist and a Philadelphia lawyer to read." Marten, supra note 2, at 358 (quoting 1 ChEM. REg. Rep. (BNA) 5-6 (Haz. Mat. Transp.) (News Summary) (July $25,1980)$ ). 


\section{The Current Framework for HMTA Preemption Decisions}

State and local regulations concerning hazardous-materials transportation may be preempted in either of two ways: by operation of the dormant commerce clause, or by operation of a federal statute like the HMTA. The dormant commerce clause invalidates state action that burdens commerce between states to an extent unjustified by the state's interest in the action. ${ }^{6}$ Although an outright ban on dangerous shipments within a state's borders no doubt fails this test, ${ }^{7}$ there is a long tradition of federal deference to more limited regulations unless they discriminate against outside industries or produce no safety benefits. ${ }^{8}$ As a constitutional matter, then, in the absence of a preemptive federal statute, states and localities are relatively free to enforce regulations that are less than outright bans unless they unduly favor local industries.

On its face, the HMTA purports to preempt any "inconsistent" state or local regulations. ${ }^{9}$ In practice, however, the scope of this statutory preemption is uncertain. DOT and the courts agree only on the two general tests for determining when state and local regulations are inconsistent with the HMTA. ${ }^{10}$ First, a local re-

- U.S. ConsT. art I, § 8, cl. 3; see Raymond Motor Transp., Inc. v. Rice, 434 U.S. 429 (1978).

7 See Washington State Bldg. \& Constr. Trades Council v. Spellman, 684 F.2d 627 (9th Cir. 1982) (Washington initiative measure banning passage of out-of-state nuclear waste into state is an unconstitutional restraint on interstate commerce), cert. denied, 461 U.S. 913 (1983); Illinois v. General Electric Co., 683 F.2d 206 (7th Cir. 1982) (Illinois statute banning transportation of spent nuclear fuel into the state for storage held unconstitutional), cert. denied, 461 U.S. 913 (1983); cf. Philadelphia v. New Jersey, 437 U.S. 617, 628 (1978) (a state may not "isolate itself from a problem common to many [(municipal waste)] by erecting a barrier against the movement of interstate trade"). See generally Annot., 82 A.L.R.3d 751 (1978) (discussing scope of state power to regulate and adjudicate with respect to nuclear power plants).

3ee Raymond Motor Transp., Inc. v. Rice, 434 U.S. 429, 443 (1978) ("In no field has .. . deference to state regulation been greater than that of highway safety regulation."); see also Bibb v. Navajo Freight Lines, 359 U.S. 520, 524 (1959) (state highway safety regulations "carry a strong presumption of validity"); South Carolina Highway Dep't v. Bamwell Bros., 303 U.S. 177, 187 (1938).

Despite the broad dicta in Raymond and Bibb, the Court struck down state regulations in both cases. In Raymond, a limit on truck length was held invalid because no safety benefit was shown and because exceptions to the law favored in-state industries. 434 U.S. at 44447. In $B i b b$, although the regulation was nondiscriminatory, it nevertheless overly burdened interstate commerce because it was directly contrary to regulation in a nearby state. 359 U.S. at 529.

49 U.S.C. \& 1811 (a) (1982).

10 Judicial interpretations of the HMTA have chosen a moderate preemption standard instead of the following two extreme possibilities. First, the HMTA might have been interpreted as preempting all local regulations except those permitted by the DOT through a 
quirement is preempted if it is impossible to comply with both the federal and local rules. ${ }^{11}$ This test poses no analytical challenge, since it is easy to determine when compliance with both local and federal law is impossible. Consequently, states have little incentive to pass such laws, and if they did, DOT or the courts would have no difficulty finding the regulations preempted.

DOT and the courts also agree that a local requirement is preempted if it "is an obstacle to the accomplishment and execution" of Congress's full purposes and objectives. ${ }^{12}$ This test is more diffi-

non-preemption determination. In such a system, all local rules would be preempted as inconsistent, with DOT's statutory non-preemption determination as the sole mechanism for local input into the pervasive scheme of federal regulation. However, nothing in the HMTA or its legislative history indicates that Congress intended to preempt the entire field of local regulations. Congress did not clearly state that it was preempting the field, as it has in other areas. Instead, the HMTA only preempts "inconsistent" state requirements. Moreover, if Congress had intended to occupy the field there would have been no reason to impose a twostep scheme of inconsistency rulings followed by non-preemption determinations-only the latter procedure would ever be needed. Courts and commentators overwhelmingly agree that the HMTA does not preempt all local regulation of hazardous materials transportation. See, e.g., New Hampshire Motor Transp. Ass'n v. Flynn, 751 F.2d 43, 46 (1st Cir. 1984); National Tank Truck Carriers, Inc. v. Burke, 608 F.2d 819, 820 (1st Cir. 1979); Chemclene Corp. v. Pennsylvania Dep't of Envtl. Resources, 497 A.2d 268, 272-73 (Pa. Commw. Ct. 1985).

The HMTA could also have been interpreted as preempting only local regulations that set standards lower than federal standards or that unreasonably burden interstate commerce. This "minimalist" interpretation would preserve the traditional presumptions of federalism in the area of traffic regulation, but would render the HMTA's preemption provisions and procedures essentially meaningless. Even without the HMTA, any local rule that unreasonably burdens interstate commerce is invalid under the dormant commerce clause. See supra notes 6-8 and accompanying text. Furthermore, where federal standards exist it is futile for local authorities to set lower safety standards, since shippers would have to obey the stricter federal laws anyway.

The minimalist interpretation also undermines Congress's purpose in the HMTA "to preclude a multiplicity of State and local regulations and the potential for varying as well as conflicting regulations in the area of hazardous materials transportation." S. REP. No. 1192, supra note 4, at 37 . If Congress had wanted to set only a federal "floor," it could have used language that did so more explicitly, as it has in other areas. See, e.g., Interstate Commerce Act, 49 U.S.C. $\$ \S 301-327$ (1982) (regulating the trucking industry generally); see also Federal Motor Carrier Regulations, 49 C.F.R. $\$ 390.30$ (1985) (ICA regulations "are not intended to preclude States or subdivisions thereof from establishing or enforcing State or local laws relating to safety, the compliance with which would not prevent full compliance with these regulations by the person subject thereto."). The courts and DOT seem largely to have implicitly rejected the minimal preemption interpretation. See, e.g., 49 C.F.R. $\S 107.221(b)(1)-(b)(4)(1984)$ (DOT imposes requirements for non-preemption beyond those in the statute, implicitly rejecting minimalist preemption); Kappelmann v. Delta Air Lines, 539 F.2d 165, 169-70 (D.C. Cir. 1976) (emphasizing need for national uniformity-an implicit rejection of minimalism), cert. denied, 429 U.S. 1061 (1977).

11 Compare 49 C.F.R. $\$ 107.209$ (c)(1) (1984) (impossibility is the first inquiry in determining inconsistency), with Ray v. Atlantic Richfield Co., 435 U.S. 151, 158 (1978) (conflict will be found when compliance with both regulations is "a physical impossibility") (quoting Florida Lime \& Avocado Growers, Inc. v. Paul, 373 U.S. 132, 142-43 (1963)).

12 Compare 49 C.F.R. $\$ 107.209$ (c)(2) (1984), with Ray, 435 U.S. at 158 (quoting Hines 
cult than the first, since it looks to the purposes behind the HMTA and their relative importance. Unfortunately, nothing in the HMTA or its legislative history indicates what weight to give each of Congress's concerns. Furthermore, the HMTA creates a peculiar procedural framework for preemption decisions that undermines uniformity. Thus, DOT and the courts have struggled to ascertain how Congress struck the balance between local and national interests.

\section{A. Statutory Standards and Procedure}

Under the HMTA the preemption question may be decided in two steps. First, a local requirement may be preempted only if it is determined to be "inconsistent" with the HMTA, either by DOT in an administrative proceeding called an "inconsistency ruling" or by a court deciding a suit for injunction or enforcement of the local requirement. ${ }^{13}$ Second, even if a requirement is inconsistent, the HMTA provides that it will not be preempted if, on the application of an appropriate state agency, DOT essentially waives preemption by determining that the requirement " $(1)$ affords an equal or greater level of protection to the public than is afforded by the requirements of this chapter or of regulations issued under this chapter; and (2) does not unreasonably burden commerce."14 Thus, the validity of a local regulation might be determined by DOT in an inconsistency ruling, by a court in an action disputing the validity of the local law under the HMTA, or by DOT in a non-preemption determination.

This scheme breeds disagreement in several ways. Most important, it creates the possibility of conflicting approaches, since

v. Davidowitz, 312 U.S. 52, 67 (1941)). See generally Laurence Tribe, American ConstituTIONAL LAW \$§ 6-24 (1978) (discussing approaches to determining preemption). The existence of a dominant federal interest or a need for uniformity may buttress a conclusion of invalidity under the full-purposes test. See, e.g., Fidelity Fed. Sav. \& Loan Ass'n v. de la Cuesta, 458 U.S. 141, 153 (1982); Rice v. Santa Fe Elevator Corp., 331 U.S. 218, 230 (1947). Courts may also examine the legislative history of a bill to decide whether there is a need for uniformity. Florida Lime \& Avocado Growers, Inc. v. Paul, 373 U.S. 132, 146-50 (1963); Illinois v. Kerr-McGee Chem. Corp., 677 F.2d 571, 579 (7th Cir.), cert. denied, 459 U.S. 1049 (1982).

DOT has largely accepted these principles as stated by courts. See National Tank Truck Carriers, Inc. v. Burke, 535 F. Supp. 509, 515 (D.R.I. 1982) (noting DOT's adoption of traditional judicial tests), aff'd, 698 F.2d 559 (1st Cir. 1983); General Preamble to Inconsistency Rulings IR-7 Through IR-15, 49 Fed. Reg. 46,632, 46,633 (1984) ("Given the judicial character of the inconsistency ruling proceeding, [DOT] has incorporated into it case law criteria.").

1349 C.F.R. $\$ \S 107.201-.211$ (1984).

1449 U.S.C. § 1811(b) (1982). 
neither DOT nor the courts has exclusive authority to determine preemption standards. At the same time, it increases the potential for conflict by allowing courts to act with little or no input from DOT at any stage of the proceedings. In the first place, courts have decided that the HMTA does not grant DOT primary jurisdiction over preemption issues, which would require parties to exhaust their administrative remedies by seeking an inconsistency ruling from DOT before going to court. ${ }^{15}$ Thus, parties can challenge regulations in court without ever having approached DOT. Second, DOT will not hold a non-preemption proceeding unless the locality concedes inconsistency or has the issue decided against it. ${ }^{16}$ Thus, localities are not likely to seek non-preemption determinations until after they have lost protracted litigation. Third, DOT does not submit amicus briefs to give courts the benefits of its views on the inconsistency and merit of local laws. ${ }^{17}$ Thus, DOT can be completely bypassed under the HMTA until a party seeks a non-preemption determination, which is not available until after a court rules in favor of preemption.

Even if DOT were to rule on inconsistency before a court did, DOT's ruling might not have any effect. In contrast to DOT's explicit authority to make rules in certain areas, DOT's inconsistency

13 The doctrine of primary jurisdiction generally requires that courts postpone consideration of a problem within the special competence of an administrative agency. It is usually applied when resolution of the problem at hand requires technical as opposed to judicial expertise, or when the statutory scheme suggests a need for uniform decisions that an agency can provide. See, e.g., United States v. Western Pacific R.R., 352 U.S. 59, 64 (1956); Kappelmann v. Delta Air Lines, 539 F.2d 165, 168-69 (D.C. Cir. 1976), cert. denied, 429 U.S. 1061 (1977). See generally Kenneth C. Davis, 4 Administrative Law Treatise \$§ 22:1-:11 (2d ed. 1983) (discussing primary jurisdiction).

Deciding whether a statute is preempted is, however, a traditional judicial task for which DOT may not have special expertise. Moreover, there is no particular reason to suppose that Congress intended courts to defer to DOT on this issue. See National Tank Truck Carriers, Inc. v. Burke, 608 F.2d 819, 821-23 (1st Cir. 1979); City of New York v. Ritter Transp., Inc., 515 F. Supp. 663, 668 (S.D.N.Y. 1981), aff'd sub nom. National Tank Truck Carriers, Inc. v. City of New York, 677 F.2d 270 (2d Cir. 1982). DOT appears to acquiesce in this approach. See, e.g., General Preamble to Inconsistency Rulings IR-7 Through IR-15, 49 Fed. Reg. 46,632, 46,632 (1984); Inconsistency Ruling (IR-2): Notice of Decision on Appeal, 45 Fed. Reg. 71,881, 71,882 (1980).

16 See 49 C.F.R. $\$ 107.215$ (a)(4) (1984). This may explain why only two applications for non-preemption determinations have been made. See Public Notice and Invitation to Comment, 50 Fed. Reg. 2528 (1985) (application by New York City); Application for Non-Preemption Determination, 49 Fed. Reg. 3166 (1984) (application of Massachusetts Office of Transportation and Construction).

${ }^{17}$ See New Hampshire Motor Transp. Ass'n v. Flynn, 751 F.2d 43, 50 (1st Cir. 1984). DOT evidently declines to submit amicus briefs because this might amount to issuing an inconsistency ruling without permitting the public notice and comment required by the Administrative Procedure Act. 
rulings are not made according to rulemaking authority under the HMTA. Consequently, they are purely advisory, for where an agency interprets a statute without rulemaking authority, its interpretation is entitled to little judicial deference. ${ }^{18}$ Unlike rulings in many other agencies, moreover, the DOT's inconsistency rulings are not reached in adversary proceedings or according to specific fact-finding procedures.

The divisive effects of this dispersion of authority are magnified by the differences in procedures before DOT and the courts, which encourage quite different evaluations of the preemption question. In some cases, DOT is likely to take into account a broader range of considerations and evidence than would a court. Inconsistency rulings require public notice and comment, ${ }^{19}$ enabling DOT to consider effects of regulations on third parties, including other jurisdictions, more competently than can a court. But at the same time, courts may take into account many factors which DOT does not: for example, a court might consider effects on interstate commerce, ${ }^{20}$ the validity of state regulations as they were applied, ${ }^{21}$ or judicially noticeable facts that are unavailable to DOT. ${ }^{22}$

\section{B. The Disagreement}

1. DOT's Position. DOT's views on preemption have gradually emerged from its regulations, its general statements of policy, and the 16 inconsistency rulings made to date. ${ }^{23}$ Not surprisingly,

${ }^{18}$ See Inconsistency Ruling (IR-2): Notice of Decision on Appeal, 45 Fed. Reg. 71,881, 71,882 (1980); see also General Preamble to Inconsistency Rulings IR-7 Through IR-15, 49 Fed. Reg. 46,632, 46,632 (1984) (determination of inconsistency is " traditionally judicial in nature' ") (quoting 41 Fed. Reg. 38,167 (1976)); see also General Elec. Co. v. Gilbert, 429 U.S. 125, 141 (1976) ("courts properly may accord less weight to [EEOC] guidelines than to administrative regulations which Congress has declared shall have the force of law"). See generally $2 \mathrm{~K}$. DAvis, supra note 15, $\$ \S 7: 8-: 12$ (2d ed. 1983) (distinguishing between interpretive and legislative rules).

1949 C.F.R. § 107.205 (1984).

2o See infra notes $42,75$.

21 DOT rules only on the facial inconsistency of local requirements. Compare Inconsistency Ruling (IR-2): Notice of Decision on Appeal, 45 Fed. Reg. 71,881, 71,882-83 (1980) (DOT determines inconsistency by examining local requirement on its face), with National Tank Truck Carriers v. Burke, 535 F. Supp. 509, 515 (D.R.I. 1982) (reversing the above ruling) (preemption must be decided based on how federal and local requirements are applied, not solely on how they are written).

${ }^{22}$ See, e.g., American Trucking Ass'ns, Inc. v. City of Boston, 1981 Fed. Carr. Cas. if 82,938 (D. Mass. 1981) (upholding Boston routing regulations despite a DOT inconsistency ruling to the contrary because of additional facts not available to DOT).

${ }^{23}$ DOT had handed down 16 rulings as of January 1, 1986. See IR-1, 43 Fed. Reg. 16,954 (1978) (New York City); IR-2, 44 Fed. Reg. 75,566 (1979), aff'd on internal appeal, 
DOT reads the HMTA as drastically altering the traditional roles of local authorities over hazardous-materials transportation: ${ }^{24}$

Congress indicated a desire for uniform national standards in the field of hazardous materials transportation and ... gave the Department the authority to promulgate such standards. While the HMTA did not totally preclude State or local action in this area, it is [DOT's] opinion that Congress intended, to the extent possible, to make such State or local action unnecessary. The comprehensiveness of [DOT regulations] severely restricts the scope of historically permissible State or local activity. ${ }^{25}$

DOT perceives certain areas in which "the need for national uniformity is so crucial and the scope of Federal regulation is so pervasive that it is difficult to envision any situation where a State or local regulation" would not be inconsistent. ${ }^{28}$ For example, according to DOT, state and local governments may not issue requirements that differ from or add to federal standards governing packaging design and construction, equipment for hazardous materials shipments, hazard warning systems and classifications, marking and labeling of packages, and placarding of vehicles. ${ }^{27}$

On the other hand, DOT has also identified areas in which local regulation is not inevitably precluded. Traffic control, for example, is not amenable to exclusive nationwide regulation but is a "site-specific activity."28 Although DOT desires "uniform and con-

45 Fed. Reg. 71,881 (1980) (R.I.); IR-3, 46 Fed. Reg. 18,918 (1981) (Boston); IR-4, 47 Fed. Reg. 1231 (1982) (Wash.); IR-5, 47 Fed. Reg. 51,991 (1982) (New York City); IR-6, 48 Fed. Reg. 760 (1983) (Covington, Ky.); IR-7, 49 Fed. Reg. 46,635 (1984) (N.Y.); IR-8, 49 Fed. Reg. 46,637 (1984) (Mich.); IR-9, 49 Fed. Reg. 46,644 (1984) (Vt.); IR-10, 49 Fed. Reg. 46,645 (1984) (N.Y.); IR-11, 49 Fed. Reg. 46,647 (1984) (N.Y.); IR-12, 49 Fed. Reg. 46,650 (1984) (St. Lawrence County, N.Y.); IR-13, 49 Fed. Reg. 46,653 (1984) (N.Y.); IR-14, 49 Fed. Reg. 46,656 (1984) (Jefferson County, N.Y.); IR-15, 49 Fed. Reg. 46,660 (1984) (Vt.); IR-16, 50 Fed. Reg. 20,872 (1985) (Tucson, Ariz.). Hereinafter these rulirigs will be cited simply as "IR-1," "IR-2," and so forth.

${ }^{24}$ See, e.g., Inconsistency Ruling (IR-2): Notice of Decision on Appeal, 45 Fed. Reg. $71,881,71,883$ (1980).

${ }^{2 s}$ General Preamble to Inconsistency Rulings IR-7 Through IR-15, 49 Fed. Reg. $46,632,46,633$ (1984).

28 Id.

27 IR-2, at 75,567. For examples of inconsistency rulings enforcing these principles, see IR-16, at 20,874 (class definitions); IR-15, at 46,660 (same); IR-12, at 46,651 (same); IR-8, at 46,637 (same); IR-6, at 763 (same); IR-5, at 51,993-94 (same); IR-3, at 18,924 (placarding); cf. IR-4, at 1232-33 (state requirement of red-bordered shipping papers is inconsistent; analogy drawn to these areas on grounds that uniformity is central here too).

28 HM-164, "Radioactive Materials; Routing and Driver Training Requirements," 46 Fed. Reg. 5298, 5300 (1981). 
sistent rules for route selection," it has admitted that it cannot develop sufficient knowledge of site-specific conditions to regulate them as effectively as local authorities can. ${ }^{2 \theta}$ Local authorities are well-suited to select routes because they have intimate knowledge of local conditions and strong incentives to protect the safety of their constituents. Nevertheless, DOT has hesitated to leave the area completely to local authorities because they are "inherently limited in perspective," expertise, and manpower and are unaccountable to persons outside their immediate jurisdiction. ${ }^{30}$ In other words, they are likely to attempt to divert hazardous-materials traffic into other jurisdictions.

DOT attempted to mediate these conflicting concerns by circumscribing the range of local routing regulation to the selection of "preferred routes." Un1 Under this scheme, certain high-risk shipments may travel only over highways designated as "preferred routes," barring exceptional circumstances. Roads within the interstate highway system are preferred routes automatically, but states may designate other roads as preferred routes. A state may even remove an interstate highway from the list of preferred routes if it specifies an equivalent alternative route. Thus, on the basis of local conditions states may dictate to shippers which routes they may use. ${ }^{32}$

To limit local participation in this manner, however, DOT also issued a general statement of policy indicating that any other "routing rule" will probably be found inconsistent. ${ }^{33}$ DOT has even suggested that if a state can achieve its goals by selecting preferred routes, use of any other method is per se inconsistent..$^{34}$ In particular, DOT has announced that it will find a rule inconsistent with the HMTA if the rule requires additional or special personnel, equipment, or escort;"35 requires additional or different shipping pa-

28 Id. at 5301.

so Id.

s1 See 49 C.F.R. $\$ 177.825$ (1984).

s2 Id. DOT has published a pamphlet containing extensive guidelines to aid states in choosing such routes. Dep't of Transportation, Guidelines por Selecting Preferred Highway Routes por Shipments of Large Quantity Radionctive Materials (1981).

ss 44 C.F.R. Part 177, Appendix A (1984) [hereinafter "Appendix A"]. Unlike a regulation or inconsistency ruling, Appendix A does not impose any duty to act or have the force of law, but merely states DOT policy and assists local authorities that are considering regulation. The State of Ohio has challenged Appendix A on the grounds that it constitutes rulemaking without the public input required by the Administrative Procedure Act. See Ohio ex rel. Celebrezze v. Department of Transp., 766 F.2d 228 (6th Cir. 1985) (finding that Ohio has standing and remanding for a trial on the merits).

st See IR-8, at 46,640; see also IR-15, at 46,667 .

ss Appendix A, VI(B). For examples of enforcement, see IR-15, at 46,664 (requiring 
per entries, placards, or other hazard warning devices; ${ }^{36}$ requires filing route plans or other documents containing information that is specific to individual shipments; ${ }^{37}$ requires accident or incident reporting other than what is immediately necessary for emergency assistance; ${ }^{38}$ or "unnecessarily" delays transportation. ${ }^{38}$

In addition, DOT's inconsistency rulings consistently utilize certain arguments of general applicability in deciding particular cases. These rationales often overlap, and usually at least one can be found to attack any local rule. If accepted, these rationales would make it possible in effect to limit the state and local regulation to the choosing of preferred routes.

First, if the local regulation covers the same ground as a federal regulation, DOT can invalidate it as "redundant" or "confusing." DOT reasons that if a requirement duplicates existing DOT regulations, it is superfluous; to the extent it differs from the federal regulations, it may confuse shippers, thus decreasing compliance and reducing safety..$^{40}$ Second, even if there is no conflicting federal regulation, the mere possibility that other states might pass conflicting rules makes the local regulation inconsistent, since Congress wanted to preclude a multiplicity of state and local requirements. ${ }^{41}$

special escort not valid grounds for user fee); IR-8, at 46,638 (requiring different communications equipment inconsistent).

so Appendix A, VI(C); cf. IR-4, at 1233 (invalidating requirement of red-bordered shipping papers).

${ }^{37}$ Appendix A, VI(D). For examples of enforcement, see IR-15, at 46,661-62 (prenotification inconsistent); IR-14, at 46,657 (same); IR-12, at 46,652 (permit requirement inconsistent); IR-11, at $46,648-49$ (same); IR-8, at 46,640 (prenotification and permit requirements inconsistent); IR-6, at 765-66 (same).

3s Appendix A, VI(F). For examples of enforcement, see IR-8, at 46,643 (requirement of notice of delays inconsistent); $c f$. IR-3, at 18,924 (inconsistent to require notice umless it is necessary for emergency response).

s9 Appendix A, VI(G). This vague requirement echoes an equally vague regulation at 49 C.F.R. § 177.853 (1984).

to See, e.g., IR-15, at 46,663 (various requirements held redundant and confusing); IR14 , at 46,659 (requiring shippers to consider the effects of inclement weather is redundant); IR-8, at 46,637-41 (various requirements held redundant and confusing); IR-5, at 51,994 (complexity of regulations is often cited as a significant cause of non-compliance, so added complexity will reduce compliance and decrease safety); IR-4, at 1233 (state requirement of red-bordered paper might confuse and lead safety personnel to rely on red borders while ignoring more comprehensive federal requirements); IR-2, at 75,571 (redundancy does not further safety and causes multiplicity of rules HMTA was supposed to prevent); Inconsistency Ruling (IR-2): Notice of Decision on Appeal, 45 Fed. Reg. 71,881, 71,883 (1980) (redundant requirements are the "clearest example of the kind of multiplicity" that the HMTA was intended to prevent).

41 See, e.g., IR-15, at 46,664 (if Vermont could impose user fee to fund extra emergency-response teams so could other states, resulting in multiplicity); IR-14, at 46,659 (if 
DOT's third and fourth inconsistency rationales are closely related: state regulations will be found invalid if they unnecessarily divert $^{42}$ or delay ${ }^{43}$ shipments of hazardous materials. These rationales are based on the premise that diversion and delay increase shippers' costs, and may well increase the public's exposure to risk. Fifth and finally, DOT considers any state regulation to be preempted if it attempts to impose on shippers a burden that the state itself should rightly bear. ${ }^{44}$ For example, under this rationale, the HMTA would prohibit a state from abdicating its own obligation to provide emergency planning by compelling shippers to do so.

2. Court Views. Although few cases involving HMTA preemption have been resolved in the courts, ${ }^{46}$ the case law to date suggests that DOT's approach has not captivated the judges. ${ }^{46}$

county could close its bridges to traffic in hazardous materials during the winter, others could do so, causing multiplicity); IR-8, at 46,641 (if Michigan could impose special requirements on shippers for emergency planning, so could other jurisdictions, leading to multiplicity); IR-6, at 765 (if county could require prenotification, so could others, leading to safetydecreasing delays as trucks stop before entering each hamlet).

42 See, e.g., IR-15, at 46,664 (user fee to pay for extra emergency-response facilities will divert traffic into other jurisdictions); IR-12, at 46,652 (permit requirements divert traffic); IR-11, at 46,649 (same); IR-10, at 46,647 (indemnification requirements divert traffic); IR-8, at 46,638 (requiring different equipment may discourage shippers from using otherwise desirable route); IR-6, at 765 (even the threat of delay may divert shippers into other routes, thrusting the problem on unprepared jurisdictions); IR-3, at 18,921 (same).

There is considerable difficulty with DOT's claim that Congress has authorized it to consider the issue of diversion in determining inconsistency. Congress may well have intended that such effects would be considered in the non-preemption determination instead. Indeed, DOT has stressed repeatedly that effects on interstate commerce should not be considered at the inconsistency ruling level. See, e.g., General Preamble to Inconsistency Rulings IR-7 Through IR-15, 49 Fed. Reg. 46,632, 46,633 (1984); see also infra note 75.

4s See, e.g., IR-16, at 20,879 (prenotification requirements might delay shipments); IR10 , at 46,646 (requiring indemnification deters shippers from using thruway, increasing transit times and thus decreasing overall safety); see also 49 C.F.R. $\S 177.853$ (a) (1984) (requiring hazardous materials to be transported without unnecessary delay).

4 See, e.g., IR-8, at 46,641 (requiring shippers to tailor training of drivers to specific routes is an effort to shift the "innately governmental responsibility" of emergency preparedness from the government to the shipper); cf. IR-15, at 46,640,46,662-63 (state cannot ask shipper to provide information that the state gets from another source already; state also cannot charge user fee for program that duplicates available federal efforts in emergency response to nuclear traffic); IR-8, at 46,640 (state cannot require shippers to provide facts that the state can derive from information it gets under the HMTA anyway).

is DOT, on the other hand, has received at least 34 requests for inconsistency rulings. See Application for Inconsistency Ruling (IRA-34), 50 Fed. Reg. 45,186 (1985). Some of these were later withdrawn or consolidated with other applications, so that the number of actual disputes involved is somewhat smaller.

46 This discussion excludes cases which merely sort out roles among different federal agencies, see, e.g., Akron, C. \& Y.R.R. v. ICC, 611 F.2d 1162, 1169 (6th Cir. 1979) (discussing the ICC's role after the HMTA), cert. denied, 449 U.S. 830 (1980); Delta Air Lines, Inc. v. 
There are three major precedents: the Burke, Ritter, and Flynn cases. ${ }^{47}$ The Burke cases presented the first major controversy over HMTA preemption, and the court adopted an approach to preemption that was similar to DOT's approach. In Burke, an association of shippers sought to enjoin the enforcement of Rhode Island's "emergency regulations" concerning shipment of liquid energy gases to public utilities. These rules required shippers to obtain a state permit, obey a curfew, carry certain equipment, and make written accident reports to the state..$^{48}$ After a lengthy procedural minuet, ${ }^{49}$ a DOT inconsistency ruling issued, followed by a district court injunction, each concluding that the Rhode Island

CAB, 543 F.2d 247, 255-56 (D.C. Cir. 1976) (discussing the FAA's and CAB's roles after the HMTA), and those which involve obviously preempted local requirements, see, e.g., Jersey Cent. Power \& Light Co. v. Township of Lacey, 772 F.2d 1103 (3d Cir. 1985) (ordinance prohibiting the importation and storage of radioactive waste within a township) (appeal pending); South Dakota Dep't of Pub. Safety v. Haddenham, 339 N.W.2d 786 (S.D. 1983) (statute restricting the transportation of fireworks that did not allow rail, water, or air transport).

17 The Burke and Ritter disputes exemplify the extraordinary procedural complexity of HMTA preemption disputes. The Burke controversy ultimately resulted in two district court rulings, two appeals to the First Circuit, a DOT inconsistency ruling, and an intraagency appeal therefrom. See National Tank Truck Carriers v. Burke, 608 F.2d 819 (1st Cir. 1979) [hereinafter Burke I], on remand, 535 F. Supp. 509 (D.R.I. 1982) [hereinafter Burke II], aff'd, 698 F.2d 559 (1st Cir. 1983) [hereinafter Burke III]; see also IR-2; Inconsistency Ruling (IR-2): Notice of Decision on Appeal, 45 Fed. Reg. 71,881, 71,882 (1980).

Similarly, the dispute in Ritter continued long after the judicial phase of the dispute-a state court injunction and a federal district court refusal to vacate on removal-had found the local regulations to be valid. See City of New York v. Ritter Transp., Inc., 515 F. Supp. 663 (S.D.N.Y. 1981), aff'd sub nom. National Tank Truck Carriers, Inc. v. City of New York, 677 F.2d 270 (2d Cir. 1982). Shortly after the Second Circuit's affirmance, DOT issued a statement of policy which indicated that the local regulations were inconsistent. Final Rule, HM-164, 46 Fed. Reg. 5298, 5317-18 (1981) (codified at 49 C.F.R. § 177 Appendix A (1984)) (any routing restriction which "prohibits transportation of large quantity radioactive materials by highway between any two points without providing an alternate route" is preempted).

This statement of policy was ruled invalid by a federal district court, but held valid on appeal to the Second Circuit. See City of New York v. Department of Transp., 539 F. Supp. 1237 (S.D.N.Y. 1982), rev'd, 715 F.2d 732 (2d Cir. 1983), cert. denied, 465 U.S. 1055 (1984). Local authorities then requested a non-preemption determination, see Notice and Request for Comments, 50 Fed. Reg. 2528 (1985), while another state attacked the statement of policy in another circuit, see Ohio ex rel. Celebrezze v. Department of Transp., 766 F.2d 228 (6th Cir. 1985).

${ }^{48}$ Burke II, 535 F. Supp. at 512-13.

19 See IR-2. The request for an inconsistency ruling was entered just before the first hearing in district court, meaning that the court and DOT were considering the matter contemporaneously. Originally, the district court had issued only a temporary injunction, feeling obliged to wait for a DOT ruling. On appeal from that injunction, the First Circuit ruled that the district court need not defer to DOT. Burke I, 608 F.2d at 822 . Before the district court concluded its proceedings on remand, however, the DOT ruling was handed down. Burke II, 535 F. Supp. at 513-14. 
regulations were largely inconsistent with the HMTA.

Like DOT, the district court in Burke emphasized the need for national uniformity and the potential mischief resulting from varying and conflicting state requirements. ${ }^{50}$ Specifically, the court saw a conflict between Rhode Island's requirement of a permit and a curfew and DOT's prohibition against "unnecessary delay" in shipment. ${ }^{\text {s1 }}$ It also considered the requirement for written accident reporting inconsistent because of the "imperative" need for uniform national standards on written reports. ${ }^{.2}$ Each of these holdings echoed DOT's inconsistency ruling, and each is consistent with later DOT arguments that such requirements are invalid. ${ }^{\text {B }}$

DOT's positions found far less favor in the Ritter cases. ${ }^{54}$ There the New York City Fire Department promulgated regulations that prohibited the transportation of hazardous gases within the city unless no practical alternative route existed and the transporter received permission from the Fire Commissioner. ${ }^{55}$ Ritter's truck sprang a leak while transporting liquefied petroleum gas across the George Washington Bridge in violation of the regulations. Although no explosion occurred, the accident forced authorities to close the bridge to traffic for eight hours, causing monumental traffic jams. The city then obtained an ex parte restraining order against Ritter in state court that prohibited further violations of the regulations. On removal to federal court, Ritter sought to have the order vacated..$^{56}$

At that time DOT had not yet passed its own routing regulations, so there was no obvious preemption by duplication or physical impossibility. ${ }^{57}$ Rather, Ritter argued that the routing regulations, like the curfew requirements struck down in Burke, were inconsistent with DOT's regulation prohibiting unnecessary delay. The district court rejected this argument and upheld the restraining order, noting that the federal regulation on unnecessary delay was not intended to speed transportation "for its own sake," but to protect the public from prolonged exposure to hazardous

so Id. at 516.

5149 C.F.R. § 177.853(a) (1980); see Burke II, 535 F. Supp. at 517-19.

${ }^{32}$ Burke II, 535 F. Supp. at 519.

ss The First Circuit affirmed the district court on appeal "substantially for the reasons stated in its opinion." Burke III, 698 F.2d at 559.

st City of New York v. Ritter Transp., Inc., 515 F. Supp. 663 (S.D.N.Y. 1981), aff'd sub nom. National Tank Truck Carriers, Inc. v. City of New York, 677 F.2d 270 (2d Cir. 1982).

${ }^{8 s}$ New York City Fire Dep't Regulations F.P. 5-63 §§ 10.2, 10.4b (1980).

${ }^{s e}$ Ritter, 515 F. Supp. at 665.

${ }^{87}$ Id. at 669 . DOT has since promulgated regulations on the subject. See supra notes 31-34 and accompanying text. 
materials sitting on the street. ${ }^{58}$ The court adopted a balancing approach, emphasizing the special safety needs of densely populated areas and the greater competence of local authorities in solving local problems. ${ }^{39}$ The court also found that New York's regulation was far less disruptive to interstate commerce than was Rhode Island's regulation in Burke: New York's rule affected only a single highly congested area, whereas Rhode Island's rule, by requiring shippers to add equipment to their trucks, affected commerce outside the state. ${ }^{60}$

The spirit of the Ritter opinion is profoundly hostile to DOT's approach. Whereas DOT takes the view that an outright ban on transportation through a jurisdiction is per se inconsistent with the HMTA, and emphasizes the need for national uniformity, the courts in Ritter approached the problem by balancing harms from delay against special local problems while emphasizing the special competence of local authorities in solving local problems.

A third distinct judicial position emerged in a 1984 case, New Hampshire Motor Transport Association v. Flynn, ${ }^{61}$ where the First Circuit upheld a state license fee of either $\$ 15$ or $\$ 25$ annually on each truckload of hazardous waste. The fee was the only provision of New Hampshire's statutory scheme that was even arguably invalid: otherwise, the state simply adopted the federal regulations and set up inspection, enforcement, and emergency response teams just as DOT had encouraged the states to do. ${ }^{62}$

After disposing of a constitutional challenge, ${ }^{63}$ the court re-

sa Ritter, 515 F. Supp. at 671.

s" See id. ("local authorities are generally in the best position to consider problems unique to their area and to tailor their rules accordingly").

so Id. at 672. On appeal, the Second Circuit affirmed this ruling, see National Tank Truck Carriers, Inc. v. City of New York, 677 F.2d 270 (2d Cir. 1982), although it noted that the definitions of hazardous materials in the regulations might be preempted and remanded for consideration of that limited issue. Id. at 275. Before the district court could decide this issue on remand, DOT issued an inconsistency ruling, holding the hazardous class definitions preempted. See IR-5, at 51,994 .

i1 751 F.2d 43 (1st Cir. 1984).

-2 Id. at 46. DOT has ruled that inspections by state personnel, far from obstructing the HMTA, are "a critical element" of the partnership between the state and federal governments. IR-15, at 46,666 .

os Responding to a challenge under the commerce clause, Flynn noted that New Hampshire incurs or might incur significant costs because of hazardous-materials traffic, including giving notice to shippers, providing inspection and enforcement forces, training emergency response personnel, rerouting traffic around accidents, cleaning up spills, and so on. 751 F.2d at 47. There is ample precedent that the commerce clause does not prevent states from charging reasonable user fees for services they provide. Id. at 46; see, e.g., Evansville-Vanderburgh Airport Auth. Dist. v. Delta Airlines, 405 U.S. 707, 715-17 (1972). Indeed, the state need not prove that all of the proceeds from the fee will be used for the 
jected the argument that the fee was inconsistent with the HMTA because it might delay shipments. The court reasoned that any such delay would be indistinguishable from delays arising from constitutionally permissible state regulations of trucking. ${ }^{64}$ Similarly, any costs that might result from the delay could not be unreasonable burdens on interstate commerce. ${ }^{65}$ The court's central assumption seems to have been that "unreasonable" has the same meaning under the HMTA as it does in commerce clause cases.

\section{A Critique}

The current approaches to preemption under the HMTA are deficient. The lack of uniformity creates costly uncertainty for everyone affected by the regulation of hazardous-materials transportation. In addition, each of the approaches is flawed.

1. The Costs of Uncertainty. Although the three major cases purport to apply the same standard (the "full purposes" test) for determining when a local rule is preempted, each emphasizes different and sometimes inconsistent concerns. Moreover, each approach differs from DOT's approach. While DOT and the courts might agree on the preemption or validity for a regulation, they frame their discussions so differently that the results are highly unpredictable. Shippers and local lawmakers must therefore make potentially costly choices among alternatives whose effects are uncertain.

For example, both Burke and Ritter purport to test local requirements under the DOT regulation against "unnecessary" delays in shipment. ${ }^{66}$ However, Burke starts from the premise that "[ $t]$ here is a sound basis for national preeminence of transportation limits," while Ritter believes that "local authorities are generally in the best position to consider problems unique to their area and to tailor their rules accordingly." some truth to them, but neither court adequately addresses the other's concern. At bottom, each rests on a different presumption

stated purpose so long as fees are a "rough approximation" of costs. Flynn, 751 F.2d at 47; see also Evansville-Vanderburgh, 405 U.S. at 715-16. The plaintiff truckers failed to show that the fees were excessive. Flynn, 751 F.2d at $48-49$.

64 751 F.2d at 51-52. The delay argument was weak since it was based on delays caused because licenses could be granted only during regular office hours. However, annual licenses were easily available.

${ }^{8 B}$ Id. at 52 .

${ }^{68} 49$ C.F.R. \& $177.853(\mathrm{a})$ (1984).

${ }^{67}$ Burke $I I, 535$ F. Supp. at 516.

${ }^{\circ 8}$ Ritter, 515 F. Supp. at 671. 
about which level of government can most effectively promote safety, with Burke favoring national uniformity and Ritter favoring the special expertise of local authorities. Yet the courts failed to address why those presumptions are appropriate for these particular regulations.

This conflict is exacerbated by the Flynn decision. Flynn's focus on the reasonableness of effects on interstate commerce corresponds with neither Burke's emphasis on national needs nor Ritter's balancing test. Moreover, a DOT ruling explicitly rejected Flynn's approach, thus making the divergence four-fold ${ }^{69}$ In fact, given the current state of the law, a shipper faced with a potentially preempted state regulation might find it impossible to identify which approach would be taken, and thus how severely the state regulation will be scrutinized.

The problems created by the confusion over preemption standards are compounded by the procedural structure of the HMTA, which creates opportunities for forum shopping and delay. A shipper may be forced to sit on a particular shipment for years while local regulations are challenged in court or before DOT, and then examined again in a non-preemption determination. ${ }^{70}$

os DOT found Vermont's user fee inconsistent with the HMTA. IR-15, at 46,664. The disagreement here does not depend on the comparative size of the two fees ( $\$ 15$ versus $\$ 1000)$. DOT's objection to the Vermont fee directly conflicts with Flynn's assumption that costs of public safety regulation justify a fee approximating those costs:

Vermont asserted that the fee is reasonable and that the deployment of trained state personnel to accompany shipments is necessitated by the fact that response groups in communities along Vermont's preferred routes are predominantly voluntary and subject to high turnover, and therefore have difficulty maintaining the skills needed to respond to nuclear transportation emergencies .... However, this [limited capacity for emergency response] is the result of the State's deliberate decision . . . to field a completely independently response team rather than to rely on available Federal resources. . . . By requiring transporters to pay a fee, Vermont seeks to transfer the financial burden of its decision to replicate Federal efforts.

Id. As of mid-1983, at least 13 other states imposed user fees of some kind on shippers of hazardous materials, ranging from Ohio's tax of $\$ 3$ per vehicle to New Jersey's of $\$ 50$ per vehicle. Some states also impose a tax on each shipper regardless of the number of vehicles. For example, California charges $\$ 50$ per shipper as well as $\$ 15$ per vehicle. 1983 Hearings, supra note 1 , at 298 . An Illinois law currently under examination by DOT imposes a $\$ 1000$ fee on each cask of nuclear waste passing through the state. See 50 Fed. Reg. 45,186 (1985).

7o For example, the National Assurance Corporation had to store a large amount of nuclear waste in temporary facilities for almost two years while awaiting DOT rulings on a farrago of local rules effectively blocking a shipment mandated by a U.S. agreement with Canada. See General Preamble to Inconsistency Rulings IR-7 Through IR-15, 49 Fed. Reg. $46,631,46,635-36$. A shipper threatened with large fines or police roadblocks will probably take little solace from the possibility that it may win in the end. Moreover, even a regulation that is likely to be held inconsistent may deter a rational shipper. Consider a shipper facing a choice between a direct route through Illinois, which asserts the right to impose a $\$ 1000$ fee on each cask of nuclear waste transported through the state, see supra note 69 , and a 
At the same time, this procedural complexity may hinder the effectiveness of local safety standards, even when the standards would ultimately be found consistent with the HMTA. For example, although a DOT ruling or policy statement is not binding on the courts, a ruling that a state requirement is inconsistent may embolden shippers to ignore the requirement. Their noncompliance may well undermine safety. Such violations also are likely to be extremely difficult for local governments to detect and prosecute. And the period of uncertainty may extend for years: almost five years have passed since the near disaster in Ritter, and it is not yet clear whether the HMTA preempts New York City's regulations banning shipments of hazardous materials on heavily traveled expressways. Similarly, a recent attempt by the New Jersey Turnpike Authority to block a shipment of radioactive waste came to naught because the shipments were completed while the case was on appeal. ${ }^{11}$

Even where localities get shippers to comply with their standards, gamesmanship among jurisdictions will continue to frustrate any constructive cooperation. If some jurisdictions succeed in diverting the risks of hazardous material transportation into neighboring areas, their neighbors may feel compelled to forgo cooperation with them and with the federal government in order to protect their own citizens. For example, Vermont, one of the first states to participate in DOT's scheme of naming alternate preferred routes, ${ }^{72}$ was understandably alarmed to learn that some shippers found Vermont routes relatively attractive in light of the restrictive rules of her neighbors. Feeling that it was being punished for cooperating with DOT, Vermont enacted its own restrictive regulations, among them a requirement that shippers explain why they chose a Vermont route, with the proviso that "avoidance or circumvention" of other jurisdictions because of their rules could not be a valid reason. ${ }^{73}$

The consequences are completely antithetical to the unifica-

second route through a jurisdiction imposing no additional local requirement. Even if the probability is $90 \%$ that the Illinois fee will be preempted, a $10 \%$ chance of paying a $\$ 1000$ fee is equivalent to at least a $\$ 100$ added cost per cask. Thus a rational shipper would probably use the second route, even if doing so might increase its costs slightly. In general, the local restriction will succeed in diverting traffic unless it is certain to be found inconsistent, and certainty is sadly lacking in HMTA preemption today.

${ }^{71}$ See New Jersey Turnpike Auth. v. Jersey Cent. Power, 772 F.2d 25 (3d Cir. 1985) (dismissing the case for mootness).

72 See IR-15, at 46,665.

7s Id. DOT was characteristically insensitive to Vermont's concern, finding the "avoidance or circumvention" standard inconsistent with the HMTA. 
tion that was sought under the HMTA. Although DOT cannot bind the courts, it can frustrate local enforcement by discouraging both the passage of new laws and obedience to established ones. At the same time, however, local authorities determined to impede particular shipments can harass shippers enough to delay or divert their shipments. In the end, neither national uniformity nor local regulation is promoted, and those determined to undermine the collective good--be they obstreperous shippers or unreasonable local authorities-can do so almost at will.

2. The Need for a New Analytical Approach. The problem goes beyond mere divergence of views. Even if DOT and all the courts followed the same approach, each approach used to this date is flawed. To begin with, the rationales DOT has utilized to circumscribe state regulation are much too broad. Since DOT's rulings are only "advisory opinions," these flaws make it unlikely that even the most sympathetic court will enforce DOT's vision of national supremacy. For example, DOT's concern about redundancy and confusion seems to assume that layered regulations will cause an increase in undetected violations of federal standards; yet an equally plausible prediction is that shippers will simply learn and obey the clearest set of rules they can discern, probably those issued by DOT. Likewise, in preempting regulations that cause unnecessary delay, DOT has never explained why delays necessarily are unsafe. Not all delays increase net risk; the issue largely turns on the relative population densities of the areas at risk during the delay. ${ }^{74}$

In addition, although DOT correctly concludes that a "multiplicity" of regulations might impair compliance, it exaggerates its likely effects. Not all conflicts between the regulations of different jurisdictions are so costly that they require a federal standard; otherwise Congress likely would have adopted a broader statute that preempted the entire field of government regulation of hazardousmaterials transportation. Missing from DOT's approach is some means of deciding how much multiplicity is too much. The same shortcoming can be seen in DOT's "diversion" criteria. There can be no doubt that the HMTA preempts unnecessary diversion, but DOT offers no guiding principle to measure necessity-taken alone, even the most useful state regulation could impose costs suf-

${ }^{74}$ For example, while a truck's delay in New Jersey may increase the exposure of some New Jerseyites, it may avoid exposing a much greater number of people to a greater risk if the truck would otherwise be on a New York expressway during rush hour. 
ficient to cause diversion. ${ }^{75}$

DOT has not been alone in faltering; the courts' approaches have similar flaws. The Burke court, for example, put far too much emphasis on the need for uniformity. If Congress had valued only uniformity, it would have preempted all local regulation. Contrary to the court's conclusion that uniform national standards are "imperative"-even for written accident reports ${ }^{78}$ - it may be reasonable and prudent to file different accident reports with DOT and local authorities, since they may be interested in different aspects of the accident.

The Ritter court, on the other hand, was a bit cavalier about the serious detrimental effects that a ban on passage through New York City could have on the safety of citizens in New Jersey and Connecticut. ${ }^{77}$ Indeed, neither Burke nor Ritter adequately addressed the central concern of the Flynn case and many of the DOT inconsistency rulings: the danger that local authorities may use regulation as a pretext to divert the burdens of hazardousmaterials transportation into other jurisdictions. Diversion may be the most important and difficult problem in this whole area, since states need not impose an outright ban on shipments in order to divert traffic elsewhere. Even small fees, prenotification requirements, and accident reporting rules raise the relative costs of shipping through a given locality; at the very least, they put shippers to the expense of learning the local regulations. Since those costs are imposed by jurisdictions with no incentive to consider the relative costs of. alternative routes, traffic is likely to be diverted randomly rather than in an optimal pattern. This critical aspect of the HMTA's purpose-to prevent unnecessary diversion-seemed lost on the Burke and Ritter courts.

Finally, although Flynn directly addressed the issue of diversion, it did so only by importing pure commerce clause doctrines. The court seemed to conclude that if a burden is not unreasonable under the commerce clause, it is valid under the HMTA. This ap-

${ }^{28}$ DOT's attention to diversion at the stage of the inconsistency ruling might also be criticized as contrary to its own policy of not considering burdens on interstate commerce at that time. See, e.g., General Preamble to Inconsistency Rulings IR-7 Through IR-15, 49 Fed. Reg. 46,632, 46,633 (1984). (Similar remarks have appeared in every recent notice and request for comments on applications for inconsistency rulings.) Arguably, Congress intended burdens on interstate commerce to be considered in the non-preemption determination instead. On the other hand, since DOT is required at a non-preemption hearing to hold that a rule is preempted if it finds that the rule burdens interstate commerce, it may be authorized to make that same finding at an earlier stage.

${ }^{26}$ See Burke II, 535 F. Supp. at 519.

77 See Ritter, 515 F. Supp. at 671. 
proach must be wrong, however, for if Congress intended to preclude a "multiplicity of varying and conflicting" local requirements, it must have intended to preempt at least some local laws that would be valid in the absence of the HMTA. Moreover, Flynn's approach is too limited, since it considers only the unreasonableness of burdens in isolation and not their relative effects on safety compared to other routes.

\section{Proposals for Reform}

The existing uncertainty could be alleviated to some extent simply by clarifying the terms of the debate over HMTA preemption. The precise details of judicial doctrine matter less here than does predictability of approach; any decision in a particular case will be manageable if DOT and the courts will approach each case in the same way. This section offers three different kinds of proposals. First, it suggests a new analytical framework for judicial consideration of the difficult and fact-bound questions of preemption under the HMTA. It then suggests some changes DOT could make in its regulatory approach that would reduce opportunities for procedural gamesmanship. The most complete, if unlikely, solution for these problems would be for Congress to clarify the scope of HMTA preemption. This section thus concludes by proposing legislative reform of both the substance and procedures of HMTA preemption.

\section{A. A Framework for Judicial Analysis}

A principled framework for preemption decisions starts with the central puzzle of congressional intent: Why did Congress choose to preempt some but not all local requirements? Although the legislative history does not provide a definitive answer to this question, it does suggest two obvious purposes: the prevention of regulatory balkanization ("varying and conflicting state rules") and the furtherance of public safety. ${ }^{78}$ The first purpose might encompass two quite different elements: a desire to gain the efficiencies inherent in a unified system ("uniformity") and a desire to prevent exportation of the burdens of interstate commerce into other jurisdictions ("diversion"). Yet these two elements cannot be all that

78 Compare S. REP. No. 1192, supra note 4, at 37 (endorsing preemption "to preclude a multiplicity of state and local regulations and the potential for varying as well as conflicting regulations"), with 49 U.S.C. $\$ 1801$ (1982) (the policy of Congress is "to protect the nation adequately against the risks to life and property"). 
Congress was concerned about, or it would have simply preempted all local regulation.

The balancing element must be the improvement of safety: Congress sought not only to promote uniform solutions where they are appropriate and to preclude blatant diversions, but also to permit local participation where it improved safety. ${ }^{79}$ Thus the first step in any analysis should be to recognize these three interlocking objectives: to encourage uniform national standards where such standards will promote safety better than local experimentation, to permit local regulation by those closest to the problems where local standards best promote safety, and to limit local power to export the burdens of hazardous material transportation to other jurisdictions or to unreasonably increase the costs of interstate commerce.

The initial inquiry, then, should be whether safety would be most promoted by regulation at a national or local level, taking into account the risks of diversion and non-uniformity as well as the possible benefits of more finely tuned rules. Putting the debate in these terms, of course, should not obscure the inherent problem of deciding whose safety should be considered. The conflict between local and national interests cannot be ignored; the goal set by Congress must have been improvement of net safety, however uncertain the process of netting out the gains and losses in safety to citizens of different jurisdictions.

1. The Formulation. In light of these three purposes and general preemption doctrine, a judicial approach to preemption under the HMTA should proceed through the following four steps: ${ }^{80}$

First, does the challenged rule clearly conflict with a DOT regulation because it is impossible to comply with both the local and federal standards? If so, the rule is obviously preempted and the locality must seek a waiver from DOT in a non-preemption determination.

Second, if the rule does not clearly conflict with a DOT regulation, does the local rule operate in a subject area for which a uniform national standard best promotes net safety

78 See S. REP. No. 1192, supra note 4, at 37-38 (endorsing the idea of allowing state regulations that vary from federal rules under "exceptional circumstances" and if they are "equivalent or more stringent"); see also Ritter, 515 F. Supp. at 671 (local authorities most familiar with local safety problems).

so It should be stressed that the analytical approach proposed in the text is only one good approach to determining preemption; it is not commanded by the language of the HMTA. Any other "test" which seriously considered the three concerns discussed in the text would be very helpful. 
and efficiency? If so, the rule is preempted and the locality must seek a waiver in a non-preemption determination.

Third, where national uniformity offers little advantage, does the rule increase net safety rather than merely diverting risks to other jurisdictions? That is, are the effects of diversion, delay, or increased costs justified by an increase in overall safety of all affected parties? If the rule does not survive this balancing test, it is preempted.

In applying this test, a court is likely to have little trouble with step one. In step two, a court should look first to DOT's actions. If DOT has issued regulations in the same general area, and they do not provide for local involvement, a court can presume that national uniformity is appropriate. If DOT's regulations specifically provide for local involvement, however, as in the area of preferred routes, a court can presume that local expertise is appropriate. If DOT has no regulations on point but has issued inconsistency rulings in the area, a court still might give these some deference, since DOT both has greater expertise and has access to the additional input bearing on the costs of non-uniformity that other localities are able to provide. ${ }^{81}$ Still, a court should not permit DOT to second-guess local authorities on what methods may best promote local safety in areas DOT acknowledges are amenable to local expertise. If DOT has not been willing to formulate a national standard, it should not be heard to argue that uniformity is important. Instead, a court should presume that a uniform national standard is not necessary and the local requirement is acceptable under this part of the test. A court will have to choose between national and local expertise by looking at other fact-bound considerations, such as whether the rule serves a purpose unique to the locality issuing it and whether local authorities might be in the best position to make ongoing adjustments or to achieve compliance.

A court's measurement in step three of the local rule's net effect on safety poses similar surmountable difficulties. Subtle technical problems of net safety are, after all, resolved by courts regularly under other environmental laws. Some rules of thumb may be helpful here, however, and the cases discussing diversionary effects under the commerce clause form a baseline for analysis. Where a

s1 In contrast, general statements of policy issued by DOT seem entitled to little or no deference. Unlike inconsistency rulings, which are issued only after public notice and comment, see 49 C.F.R. $\$ 107.205$ (1984), policy statements are issued by DOT on its own. 
local regulation is so burdensome as to keep traffic out of the jurisdiction entirely, rather than providing alternative routes, it may be appropriate to consider whether the local objective could have been accomplished by less restrictive means. If it could be, the local rule should be preempted (subject, of course, to DOT waiver). The question here is not limited to the minimal constitutional barrier, however; Congress may have wanted to prohibit some local actions that were otherwise constitutional. In this area, courts should exercise great deference to DOT's inconsistency rulings, since DOT has both greater expertise and special access to the additional input of other affected communities and shippers through its public notice and comment procedures. Still, a court need not defer mindlessly to DOT, but may consider the opinions of other experts.

2. Applications of the Test. A few hypothetical situations illustrate the operation of the test. First, suppose Brownsville, Texas, requires trucks carrying hazardous materials to be marked in both English and Spanish and that this rule does not clearly conflict with any DOT regulation. Hence, the rule survives step one. Nonetheless, DOT has issued regulations governing the placarding of vehicles ${ }^{82}$ and has expressed its view that localities may not issue requirements which differ from federal requirements in this area. Under step two, a court should defer to DOT's position and conclude that a national standard is best, thus preempting Brownsville's placarding rule. ${ }^{83}$ Of course, the rule might still be given effect if DOT were to grant a waiver in a non-preemption determination.

For a second example, suppose that New York City bans the transportation of certain hazardous materials on Manhattan Island and the bridges leading to it. Suppose also that the effect of the ban is to divert traffic through New Jersey. DOT has no clearly conflicting regulation, so New York's law survives step one. ${ }^{84}$ Furthermore, by DOT's own admission, the designation of appropriate

${ }_{82}$ See IR-4, at 1233; IR-3, at 18,924; IR-2, at 75,568.

${ }^{8 s}$ Thus state requirements in such areas as safety equipment standards, packaging, shipping papers, and definition of the class of hazardous materials should always be found inconsistent, for these are inappropriate subjects for local regulation. See, e.g., $1983 \mathrm{HEAR}-$ INGS, supra note 1 , at $243,245,285$. This is essentially DOT's position. See supra note 27 and accompanying text.

84 The DOT regulation on preferred routes creates no conflict with this rule; the regulation does not prohibit local bans so long as alternative preferred routes are substituted for those originally designated by DOT. See supra notes $31-34$ and accompanying text. 
routes for traffic is best left to local decisions, ${ }^{85}$ so DOT's system of "preferred routes" is not really a national standard but an attempt to force local authorities to make such decisions. ${ }^{86}$ Since a local standard is probably more appropriate, the law survives step two.

Under step three, the court now must balance the diversion with the effect on net safety. Even if it improves net safety, the fact that the diversion completely avoids the responsible jurisdiction may require a more critical inspection of the law's effect on net safety. At this stage, a court is likely to consider factors such as the relative population densities along the two routes, the ease of access for emergency response teams, and the availability of less burdensome alternatives (such as a ban that would take effect only during rush hour). ${ }^{87}$

\section{B. A New Approach for DOT}

DOT would promote uniformity if it joined the courts in adopting this analytical approach. Shippers and local authorities would then be better able to predict the validity of particular local regulations. Furthermore, while inconsistency rulings still would not bind the courts, DOT's informed conclusions about factors in the balance would carry more weight if it used the same analytical approach.

In its non-preemption determination, DOT should apply a test similar to step three of the four-step analysis outlined above, since the test in step three fits closely with DOT's statutory mandate to consider whether the local rule "affords an equal or greater level of protection to the public" than does the HMTA or its regulations

ss See supra note 29 and accompanying text.

s6 To illustrate, in its comments opposing inconsistency for the Thousand Island Bridge Authority regulations, N.Y. ADMIN. CoDE tit. 21, §§ 5503.2-.3 (1983), invalidated in IR-13, the State of New York observed that DOT chose the interstate highway system as the set of "preferred routes" because the design standards for the interstate system require a high degree of safety, especially divided highways (four lanes), limited access, and standards for sight clearance. It noted, however, that the Thousand Island Bridge, although part of the system, is an older two-lane structure bearing a heavy volume of traffic. IR-13, at 46,655 .

${ }^{87}$ Similarly, the existence of DOT regulations and programs governing emergency response should limit the possible size of user fees: states and localities should not be permitted to impose costs on shippers significantly greater than those necessary to support the emergency-response facilities that are federally recommended. $C f$. Evansville-Vanderburgh Airport Auth. Dist. v. Delta Airlines, 405 U.S. 707, 715-16 (1972) (the fee must be a "rough approximation" of the cost of the service); Pike v. Bruce Church, Inc., 397 U.S. 137, 142 (1970) ("[T]he extent of the burden [on interstate commerce] that will be tolerated will of course depend on the nature of the local interest involved, and on whether it could be promoted as well with a lesser impact on interstate activities."). 
and whether the rule "unreasonably burden[s] commerce." Ons again, this suggests that DOT in its inconsistency rulings and the courts in applying step three should be reluctant to validate a local rule that diverts traffic or increases costs, unless the net safety gains are clear. Such a presumption would allow DOT in its nonpreemption determination to apply its expertise flexibly and receive comments on the rule from third parties. Note again that DOT is not bound in its non-preemption determination by a court's finding of an "unreasonable burden" on interstate commerce; by establishing this waiver proceeding, Congress expressly committed the decision of what is unreasonable at this stage to DOT.

Since the courts will be looking for indicators of a need for national uniformity, DOT can also enact regulations in previously unregulated areas where it judges that a national standard is best. By allowing room for local participation in some areas, as it did in primary routing, DOT may be able to channel local activities in a more rational manner. In addition, DOT might provide an informational clearinghouse on the movement of hazardous materials, thus removing the localities' incentive to pass prenotification requirements that DOT finds objectionable. ${ }^{89}$ Similarly, DOT could clarify the situation for shippers by creating a clearinghouse for listing all relevant local regulations.

\section{A Proposal for Legislative Reform}

Although this comment recommends that judges reformulate HMTA preemption standards, a more appropriate and effective prescription would be legislation. ${ }^{80}$ Whatever the optimal balance

${ }^{88} 49$ U.S.C. $\S 1811(b)$ (1982); see supra note 14 and accompanying text.

${ }^{82}$ See supra note 37.

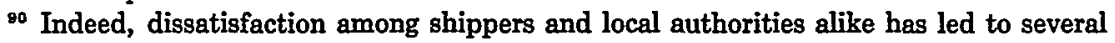
proposals for legislative reform, although none has yet borne fruit. Attempts to amend the HMTA in 1981 failed amid rancorous disputes between shippers and local governments. A coalition including both industry representatives and local authorities was formed under the sponsorship of the National League of Cities in an effort to hammer out a legislative program acceptable to both sides. The resulting bill, incorporated as Title IV of S. 1108, was introduced in 1983. See 7 Chem. Reg. Rep. (BNA) 509 (Haz. Mat. Transp.) (News Summary) (July 15, 1983). Some members of the coalition refused to support the bill. DOT suggested that it already had the authority to promulgate the changes in the bill, a claim which, if true, would reduce the measure to a funding bill for emergency-response training programs in the states. For whatever reasons, the bill was never reported out of committee. More limited and parochial legislation was introduced into the next Congress by two New York representatives seeking approval of the New York City regulations first discussed in Ritter. See also 8 Chem. Reg. Rep. (BNA) 1384, 1400 (Haz. Mat. Transp.) (News Summary) (Feb. 22, 1985). 
may be between national uniformity and local expertise, the field of hazardous-materials transportation can be broken down into subfields in which one or the other should predominate. Any legislative reform of the HMTA should center on providing clear preemption tests in those subfields in which clear tests are possible rather than trying to create a vague and universal test. In areas where uniform federal standards are appropriate, Congress should explicitly preempt all local regulations, much as it has in the regulation of automobile emissions. ${ }^{91}$ The non-preemption procedure provided in the HMTA might be continued here in the unlikely event that particular local conditions might require special consideration (e.g., in instances of extreme temperatures or of great distance to reliable emergency response services), but DOT should be given broad discretion to grant or deny such exemptions, and the meaningless standards which currently are supposed to limit its discretion $^{22}$ should be eliminated. If more experimentation seems desirable, states might be encouraged to enter into interstate compacts to promulgate such requirements, subject to congressional ratification.

Similarly, Congress should explicitly describe those areas in which states and localities can regulate. Congress should expressly oppose attempts to shift the risks of interstate commerce to other jurisdictions, and should explicitly preempt broad local requirements that have the effect of closing a jurisdiction's borders to the transportation of hazardous materials. DOT should be given authority to promulgate regulations necessary to prevent de facto border closings by overly restrictive routing requirements. ${ }^{93}$ Otherwise, Congress should clearly state that local regulation is permissible. However, in light of the possibly severe burdens and consequent deterrence of compliance if shippers are required to adhere to every minor hamlet's unpublished regulations, Congress might consider two further steps: either permitting regulation only by state agencies, or requiring localities to provide notice of their requirements to some national clearinghouse, possibly within DOT.

Besides clarifying which level of government should regulate in particular areas, Congress should consider substantial procedural reforms of the process of determining inconsistency. This

91 See 42 U.S.C. § 7543 (1982).

92 See supra notes 9,14 and accompanying text.

93 This change in the law would authorize DOT to consider diversion as a factor in inconsistency rulings, as it does currently without express authority. See supra notes 42,75 and accompanying text. 
task may be the most important one, since the courts are unable to rationalize the current ill-conceived system.

First, there should be a single forum for deciding inconsistency. Thus the procedure for inconsistency rulings could be scrapped. The availability of another forum for litigation encourages gamesmanship without improving certainty, while the lengthy period required for public comment prevents the swift resolution of conflicts that shippers need so badly. DOT should be encouraged to make policy through general regulations rather than specific adjudications.

Second, DOT's expertise on the effects of specific local regulations should be made available to courts. Thus, Congress should make DOT a party to all suits raising preemption questions, or at least should encourage judges to invite amicus briefs from DOT in appropriate cases. The elimination of the inconsistency ruling, moreover, would remove the procedural reason for DOT's reluctance to participate as amicus.94 These changes would have the added benefits of ensuring the presence in court of a party with an incentive to raise the rights of third parties, which often are implicated by the diversion of hazardous materials into other jurisdictions.

Alternatively, Congress could give DOT primary jurisdiction over rulings on inconsistency, thus requiring plaintiffs to exhaust their administrative remedies before bringing an inconsistency claim in court. ${ }^{\text {s5 }}$ Under such a scheme, DOT would consider inconsistency as a general matter and still could grant a waiver in a nonpreemption determination where it is needed to meet specific local needs. Courts would review these determinations under the "arbitrary and capricious" standard set out in the Administrative Procedure Act. ${ }^{96}$

\section{Conclusion}

The Hazardous Materials Transportation Act is still relatively young, but the uncertain scope of HMTA preemption threatens to make the Act useless. Uncertainty about the roles that the Act prescribes for different levels of government threatens safety and creates confusion in the law. If local authorities have no clear role in the system, problems requiring local expertise may go unsolved

\footnotetext{
24 See supra note 17 and accompanying text.

${ }^{95}$ See supra note 15 and accompanying text.

95 U.S.C. \& 706(2)(A) (1982).
} 
while administrative energies are wasted on clashes between local and national authority. If shippers cannot tell which laws they must obey, they may ignore important local regulations or divert shipments into inefficient or dangerous alternate routes.

This comment has attempted to outline a more helpful analytical framework for resolving disputes over HMTA preemption. Even if legislative reform is not possible, much clarity will be added to the law on HMTA preemption if the courts come to grips with the three competing concerns inherent in the HMTA and decide cases by explicitly weighing those interests within a properly constructed balancing test.

Todd Wallace 